\title{
ASO Author Reflections: Changes in Coagulation Biomarkers and the Risk for Venous Thromboembolism After Cytoreductive Surgery and Hyperthermic Intraperitoneal Chemotherapy
}

\author{
Paul Dranichnikov, MD (1) \\ Department of Surgical Science, Uppsala University Hospital, Uppsala, Sweden
}

\section{PAST}

Coagulopathy and changes in coagulation biomarkers after cytoreductive surgery (CRS) and hyperthermic intraperitoneal chemotherapy (HIPEC) is recognized but few details have been studied ${ }^{1}$ however, high plasma D-dimer on postoperative day 3 was a risk factor for postoperative venous thromboembolism (VTE) following gynecological cancer surgery. ${ }^{2}$ The reported risk for postoperative VTEs in patients with peritoneal surface malignancy is estimated as $5.6 \%$ within 60 days after surgery. ${ }^{3}$ The aim of this study was to investigate postoperative changes in coagulation biomarkers and their predictive ability for VTE.

\section{PRESENT}

The study revealed that the $6 \%$ incidence rate of symptomatic VTE within 6 months of CRS and HIPEC was similar to comparable abdominal cancer surgeries. Furthermore, the study results revealed that residual tumor at the completion of surgery, as well as elevated D-dimer on day 2, were independent risk factors for postoperative VTE.

\section{FUTURE}

D-dimer on day 2 and incomplete cytoreduction of CC2-3 may be useful clinical markers to identify patients at higher risk for VTE after surgery; this could identify

(C) The Author(s) 2021

First Received: 23 March 2021

Accepted: 24 March 2021;

Published Online: 14 May 2021

P. Dranichnikov, MD

e-mail: paul.dranichnikov@surgsci.uu.se patients in need of prolonged prophylaxis. Further research on thromboprophylaxis and on changes in post-HIPEC coagulation biomarkers is needed, particularly research investigating whether clinically relevant cut-off values for D-dimer may exist.

FUNDING Open access funding provided by Uppsala University.

OPEN ACCESS This article is licensed under a Creative Commons Attribution 4.0 International License, which permits use, sharing, adaptation, distribution and reproduction in any medium or format, as long as you give appropriate credit to the original author(s) and the source, provide a link to the Creative Commons licence, and indicate if changes were made. The images or other third party material in this article are included in the article's Creative Commons licence, unless indicated otherwise in a credit line to the material. If material is not included in the article's Creative Commons licence and your intended use is not permitted by statutory regulation or exceeds the permitted use, you will need to obtain permission directly from the copyright holder. To view a copy of this licence, visit http://creativecommons. org/licenses/by/4.0/.

\section{REFERENCES}

1. Dranichnikov P, Mahteme H, Cashin PH, et al. Coagulopathy and Venous Thromboembolic Events Following Cytoreductive Surgery and Hyperthermic Intraperitoneal Chemotherapy. Ann Surg Oncol. 2021. https://doi.org/10.1245/s10434-021-09941-9

2. Kodama J, Seki N, Masahiro S, et al. D-dimer level as a risk factor for postoperative venous thromboembolism in Japanese women with gynecologic cancer. Ann Oncol. 2010;21(8):1651-6.

3. Khan S, Kelly KJ, Veerapong J, Lowy AM, Baumgartner JM. Incidence, Risk Factors, and Prevention Strategies for Venous Thromboembolism after Cytoreductive Surgery and Hyperthermic Intraperitoneal Chemotherapy. Ann Surg Oncol. 2019;26(7): 2276-84.

Publisher's Note Springer Nature remains neutral with regard to jurisdictional claims in published maps and institutional affiliations. 